\title{
ANALISIS MAKNA KANJI KARUI (軽い), KOROBU (転ぶ), Yu (輸), RIN (論) YANG MEMILIKI Bushu Kuruma
}

\author{
Felicia \\ Japanese Department, Faculty of Humanities, Bina Nusantara University \\ Jln. Kemanggisan Ilir III No. 45, Kemanggisan, Jakarta Barat 11480
}

\begin{abstract}
Article explored the difficulties of Japanese Learners' beginners in learning kanji, especially those related to bushu kuruma, such as kanji 軽い、転ぶ、輸 and 輪, Library Research was applied by compiling corpus data taken from Kanji Modern Jepang-Indonesia. The goal of the research was to observe whether kanji 軽い、転ぶ、輸 dan 輪 had any relation to bushu kuruma. It can be concluded that those four kanji has relation to bushu kuruma, even though kanji「輪」 has no direct relation to bushu kuruma. From the four observed kanji, the three kanji「軽い」、「転ぶ」and「輪」 are included in kanji keisei moji category, a kanji that represents meaning and vocal elements, while kanji 「輸includes in the kanji kai'I moji as a meaning combination between two or more pictographs or signs.
\end{abstract}

Keywords: kanji meaning, bushu kuruma

\begin{abstract}
ABSTRAK
Artikel membahas kesulitan pemelajar pemula yang mengalami kesulitan dalam mempelajari kanji, khususnya kanji yang memiliki bushu kuruma, yaitu kanji 軽い、転ぶ、輸 dan 輪. Metode yang digunakan adalah studi pustaka dengan mengumpulkan korpus data dari dari Kamus Kanji Modern Jepang-Indonesia. Tujuan penelitian untuk mengetahui apakah kanji 軽い、転ぶ、輸 dan 輪 memiliki hubungan langsung dengan bushu kuruma. Setelah melakukan analisis pada empat kanji yang memiliki bushu kuruma, diperoleh hasil bahwa empat kanji tersebut memiliki keterkaitan dengan bushu kuruma, walaupun pada kanji 「輪」 tidak memiliki keterkaitan langsung dengan bushu kuruma. Selain itu dari empat kanji yang dianalisis, tiga kanji yaitu kanji「軽い」、「転ぶ」dan「輪」 termasuk dalam golongan pembentukan kanji keisei moji yaitu kanji yang menunjukkan elemen makna dengan elemen vocal, sedangkan kanji 「輸」termasuk ke dalam golongan pembentukkan kanji kai'i moji yang merupakan kombinasi bermakna antara dua atau lebih pictographs ataupun tanda.
\end{abstract}

Kata kunci: makna kanji, bushu kuruma 


\section{PENDAHULUAN}

Bahasa merupakan sarana dalam berkomunikasi antar sesama manusia. Pengertian bahasa menurut Keraf (1980:1): 'Bahasa adalah alat komunikasi antara anggota masyarakat berupa simbol bunyi yang dihasilkan oleh alat ucap manusia'. Bahasa bersifat dinamis, bahasa akan selalu berkembang dan mengalami perubahan. Perubahan ini dapat disebabkan oleh adanya penambahan kata-kata baru dari bahasa asing atau pengurangan karena kata tersebut tidak dipergunakan lagi. Manusia dalam berkomunikasi menggunakan bahasa lisan dan bahasa tulisan. Bahasa lisan adalah bahasa yang digunakan dalam percakapan sehari-hari baik dengan keluarga, teman maupun dengan rekan kerja. Sedangkan bahasa tulisan adalah bahasa yang digunakan dalam komunikasi tertulis seperti dalam surat, novel, komik dan lain sebagainya. Dalam mempelajari Bahasa Jepang, ada empat hal yang kita pelajari yaitu menulis membaca, mendengar dan berbicara dalam menulis, kita mengenal tiga huruf yaitu hiragana, katakana dan kanji. Huruf-huruf tersebut merupakan tulisan China yang telan dimodernisasi atau disederhanakan oleh orang Jepang. Dari ke tiga huruf tersebut, penulis akan membahas mengenai huruf kanji dengan menggunakan teori medan makna. Bagi pemelajar Bahasa Jepang pemula yang tidak terbiasa dengan tulisan kanji, tentunya mengalami kesulitan dalam mempelajari tulisan ini. Dari hutuf-huruf kanji tersebut penulis ingin meneliti mengenai kanji yang memiliki bushu (radical) kuruma (mobil). Kanji-kanji yang memiliki bushu kuruma diantaranya adalah 軌、軸、嘾 dan lain sebagainya. Diantara kanji-kanji tersebut, penulis ingin meneliti kanji 軽 い、転ぶ、輸 dan 輪 yang juga memiliki bushu kuruma.

\section{METODE}

Metode yang digunakan adalah penelitian pustaka dengan mengumpulkan korpus data dari dari Kamus Kanji Modern Jepang-Indonesia.

Tujuan penelitian untuk mengetahui apakah kanji-kanji 軽い、転ぶ、輸 dan 輪 memiliki hubungan langsung dengan bushu kuruma. Manfaat penelitian ini adalah agar dapat membantu pemelajar Bahasa Jepang dalam mempelajari kanji khususnya kanji-kanji yang memiliki bushu kuruma.

\section{PEMBAHASAN}

Kata semantik berasal dari bahasa Yunani, sema, yang bearti "tanda" atau "lambang”, yang dimaksud dengan tanda di sini adalah tanda linguistik. Oleh karena itu, semantik merupakan ilmu linguistik yang mempelajari makna atau arti dalam bahasa (Chaer, 2009: 2). Semantik sebagai pelafalan lain dari istilah "la semantique" merupakan satu cabang studi linguistik general. Semantik di sini adalah satu studi dan analisis tentang makna-makna linguistik (Parera, 2004: 24).

Selain ditinjau dari makna konotasi dan denotasi, untuk menganalisis 8 data kanji yang memiliki bushu onnahen yang terdapat dalam Kamus Kanji Modern Jepang Indonesia yang ditulis oleh Andrew N. Nelson, digunakan analisis medan makna. Pada awalnya konsep asosiasi makna dipelopori oleh Ferdinand de Saussure, disimpulkan adanya hubungan di antara seperangkat kata, misalnya dengan kata "baik, kebaikan, memperbaiki, pembaikan, perbaikan" atau "satu, satuan, penyatu, persatuan, penyatuan, bersatu, pemersatu”, kata - kata tersebut mempunyai asosiasi antar sesama (Parera, 2004: 137). 
Medan makna adalah satu jaringan asosiasi yang rumit berdasarkan pada similaritas atau kesamaan, kontak atau hubungan dan hubungan - hubungan asosiatif dengan penyebutan satu kata.

Kata semiotik berasal dari bahasa Yunani, semeion, yang berarti “tanda”, yang secara umum didefinisikan sebagai teori falsafah umum yang berkenaan dengan produksi tanda dan simbol sebagai bagian dari sistim kode yang secara sistematis digunakan untuk mengkomunikasikan informasi atau pesan secara tertulis di setiap kegiatan dan perilaku manusia , (Christomy, 2004 : 228).

Menurut Morris dalam Parera (2004: 41) mengatakan bahwa bahasa sebagai satu sistem sign dibedakan atas signal dan symbol. Akan tetapi, semiotik bukan hanya berhubungan dengan isyarat bahasa, melainkan juga berhubungan dengan isyarat-isyarat nonbahasa dalam komunikasi antarmanusia. Kita dapat mengatakan bahwa semiotika adalah ilmu isyarat komunikasi yang bermakna.

Morris dalam Christomy (2004 : 89), menjelaskan tentang tiga dimensi dalam analisis semiotik, yaitu Sintaksis semiotik, berkaitan dengan analisis yang bersifat deskriptif mengenai tanda secara individual dan kombinasinya; Semantik semiotik, berkaitan dengan analisis mengenai relasi antara tanda dan makananya; Pragmatik semiotik, berkaitan dengan analisis mengenai relasi antara tanda dan penggunanya.

Menurut Peirce dalam Christomy (2004: 117), tanda melibatkan proses kognitif di dalam kepala seseorang dan proses itu dapat terjadi jika ada representamen, acuan dan interpretan. Dengan kata lain, sebuah tanda senantiasa memiliki tiga dimensi yang saling terkait, antara lain: Representamen (R) atau sesuatu yang dapat dipersepsi (preceptiable), yaitu "wajah luar" tanda yang berkaitan dengan manusia secara langsung (sering disamakan dengan pengertian "tanda”), Objek (O) atau sesuatu yang mengacu kepada hal lain (referential), yaitu konsep yang dikenal oleh pemakai tanda berkaitan dengan representamen tersebut, dan Interpretan (I) atau sesuatu yang dapat diinterpretasikan (interpretable), yaitu penafsiran lanjut oleh pemakai tanda, setelah representamen dikaitkan dengan objek.

Menurut Peirce dalam Christomy (2004: 121 - 122), tanda (representamen) mengacu kepada objeknya (denotatum) melalui tiga cara utama, yaitu : Ikon adalah tanda hubungan antara representamen dan objeknya bersifat persamaan bentuk alamiah (keserupaan), Indeks adalah tanda yang menunjukkan adanya hubungan alamiah antara representamen dan objeknya melalui cara penunjukkannya yang bersifat kausal atau hubungan sebab - akibat, dan Simbol adalah tanda yang menunjukkan hubungan antara representamen dan objeknya bersifat arbitrer dan berdasarkan konvensi (perjanjian) masyarakat.

Dari penjelasan di atas, ada tiga contoh yang dapat dikemukakan, yaitu :

$1 \quad$ Asap yang kita lihat mengepul di kejauhan (R), dipersepsikan dan dirujuk pada suatu peristiwa kebakaran (O). Memperlihatkan (R) yang berkaitan langsung dengan (O), yang disebut dengan indeks.

2 Foto yang kita lihat (R), dirujuk pada sosok orang yang sesuai dengan foto tersebut (O). Memperlihatkan (R) yang mewakili (O), yang disebut dengan ikon.

3 Lampu merah pada rambu lalu lintas (R), kira rujuk pada makna atau konsep "berhenti” (O). Memperlihatkan (R) yang perujukannya pada (O) bersifat konvensional (disepakati oleh masyarakat), yang disebut simbol.

(Christomy, 2004: 55 - 56).

Dari proses representamen dan objek, masih berlanjut pada proses penafsiran yang disebut interpretan (I), misalnya dari contoh yang pertama, "(ada kebakaran) di daerah senen" $\rightarrow$ "mungkin proyek senen“ $\rightarrow$ "banyak pedagang kelas menengah dan kecil yang rugi“ $\rightarrow$ "perekonomian terganggu”, dan seterusnya (Christomy, 2004 : 56). 


\section{Konsep Kanji}

Dalam bahasa Jepang, pembentukan kanji disebut rikusho「六書」、menurut Henshall (1998: xvi), rikusho merupakan klasifikasi enam macam pembentukan dalam kanji, yang meliputi:

1. Pictograph atau Shoukei Moji「象形文字」. Pada dasarnya menggambarkan bentuk dari suatu benda dan biasanya cukup sederhana. Contohnya: kanji pohon「木」dari bentuk $\boldsymbol{\mathscr { * }}$, atau kanji mata 「目」dari bentuk $\theta$.

2. Simbol atau Shiji Moji 「指事文字」. Pada dasarnya sebuah tanda yang menyatakan konsep yang abstrak dan umumnya cukup sederhana. contohnya: kanji atas「上」dari konsep ニ atau kanji berputar「回」 dari konsep @

3. Ideograph atau Kai’i Moji「会意文字」。Pada dasarnya kombinasi bermakna antara dua atau lebih pictographs ataupun tanda, dan umumnya cukup sederhana. contohnya: kanji punggung bukit 「峠」、merupakan gabungan dari kanji atas $「 上 」 、 k a n j i ~ b a w a h 「 下 」 、$ dan kanji gunung 「山」。

4. Phonetic - Ideograph atau Keisei Moji「形声文字」。Pada dasarnya merupakan kombinasi antara elemen makna (semantik) dengan elemen vokal (fonetik), umumnya menunjukkan sifat umum dari suatu benda yang diwakili tersebut dan umumnya bentuk tulisannya memberikan informasi yang lebih spesifik dengan menambahkan vokal atau bunyi suara untuk menyatakan cara pengucapan (lafal) dari kata deskriptif. Contohnya: kanji menuang「注」memiliki element semantik kanji air「斗」dan element fonetik kanji utama「主」。

5. Karakter yang meminjam arti dan cara pengucapan atau Tenchuu Moji 「転注文字」。Pada dasarnya ini merupakan kanji yang arti atau cara pengucapannya (lafal) berubah, sebagai akibat dari peminjaman. Contohnya: kanji katana「刀」 memiliki makna yang diasosiasikan dengan kanji memotong 「切」dan kanji menyenangkan「楽しい」 memiliki makna yang diasosiasikan dengan kanji musik「音楽」。

6. Secara fonetik meminjam karakter atau Kasha Moji「仮借文字」。Pada dasarnya karakter yang dipinjam berdasarkan fonetik atau secara bunyi cara baca kanji yang terdengar seperti alfabetnya. Contohnya: kata Amerika menjadi kanji「亜米利加」、yang dibaca secara satu per satu berdasarkan bunyi kanjinya menjadi A-me-ri-ca, dan kata Budda menjadi kanji 「仏陀」、 yang dibaca secara satu per satu berdasarkan bunyi kanjinya menjadi Bud-da.

\section{Konsep Bushu}

Meskipun dalam beberapa kanji yang sederhana, seperti pictograph dan simbol, pada dasarnya berkarakter elemen tunggal, tetapi kebanyakan kanji menggabungkan dua atau lebih elemen. Dalam hampir semua pembentukan, ada satu elemen kunci yang dikenal dengan radikal atau bushu「部首」 yang menunjukkan sifat umum dari karakter. Radikal ini digabungkan dengan satu atau lebih elemen kanji lainnya, agar dapat memberikan informasi yang lebih spesifik, baik secara secara makna (semantik) maupun secara fonetik ( Henshall, 1998 : xix ). Menurut Henshall (1998: xx), ada tujuh posisi dasar di mana radikal dapat digunakan, seperti yang dijelaskan di bawah ini :

1. Hen 「へん」 atau Ben「べん」、merupakan bushu yang terletak di sebelah kiri. Contohnya: bushu orang 「イ」digabungkan dengan kanji berdiri「立」menjadi kanji tingkat atau pangkat 「位」、yang memberikan makna orang yang berdiri dalam suatu barisan. Bushu orang yang berada di sebelah kiri disebut ninben.

2. Tsukuri $\quad$ つくり」 atau Zukuri 「づくり」、merupakan bushu yang terletak di sebelah kanan. Contohnya: bushu memaksa「女」 dalam kanji pemerintahan「政」merupakan penggabungan dengan kanji benar「正」、yang memberikan arti menegakkan kebenaran atau membuat sesuatu menjadi benar. Bushu memaksa atau kekuatan yang berada di sebelah kanan disebut bokuzukuri. 
3. Kanmuri 「かんむり」、merupakan bushu yang terletak di bagian atas atau mahkota. Contohnya: bushu lubang atau rongga「穴」dalam kanji langit atau angkasa「空」merupakan penggabungan dengan kanji 「エ」 、yang secara fonetik memberikan arti sesuatu yang terbuka. bushu lubang atau rongga tersebut disebut kanmuri.

4. Ashi「あし」 atau shita「した」、merupakan bushu yang terletak di bagian bawah atau kaki. Contohnya: bushu hati atau perasaan 「心」 dalam kanji menahan atau memikul「忍」 merupakan penggabungan dengan kanji ujung dari suatu pedang「刃」、yang memberikan makna secara fonetik menanggung atau menahan, yang secara konotasi sesuatu yang menyakitkan dan tidak menyenangkan. Bushu hati yang terletak di bawah disebut shitagokoro.

5. Kamae「かまえ」atau gamae「がまえ」、bushu yang terletak di bagian luar atau bingkai. Contohya: bushu pintu atau gerbang「門」yang digabungkan dengan kanji hari「日」menjadi kanji periode atau jangka waktu「間」. Bushu pintu tersebut disebut kadogamae.

6. Tare 「たれ」 atau dare「だれ」、merupakan bushu yang menggantung. Contohnya: bushu bangunan「广」dalam kanji toko「占」 merupakan penggabungan dengan kanji 「占」、yang memberikan makna secara fonetik menampilkan sesuatu. Bushu bangunan ini disebut madare.

7. Nyoo 「によう」、merupakan bushu yang berbentuk seperti huruf "L". Contohnya: bushu perpindahan 「之」dalam kanji kemajuan 「進」 merupakan penggabungan dengan kanji $\lceil$ 隹」、 yang memberikan arti berpindah atau bergerak maju seperti burung. Bushu perpindahan ini disebut shinyoo atau shinyuu.

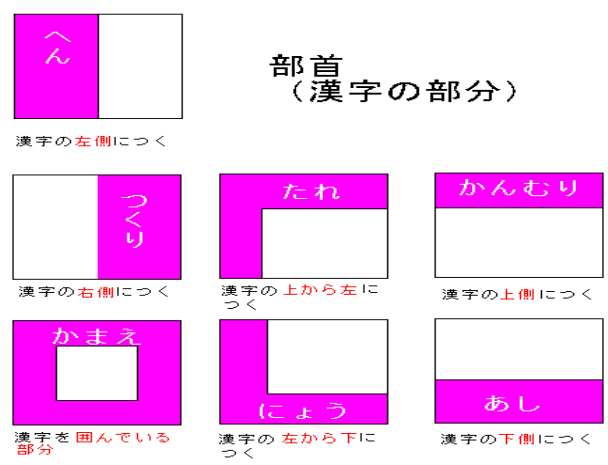

Sumber : http://一般.常識.biz/article/110948259.html

\section{Konsep Pembentukan Kanji Kuruma「車」}

Apabila bushu kuruma terletak di sebelah kiri kanji, maka bushu ini disebut kurumahen (Nelson : 864 ). Berikut ini adalah gambar pembentukan kanji kuruma menurut Toudou (1982: 944).

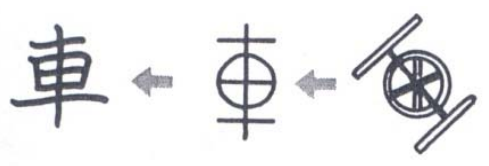

Gambar 1

Pada jaman dahulu, mobil yang dinaiki oleh manusia adalah mobil yang menggunakan tenaga manusia (人力車)、 tenaga kuda(馬車) atau tenaga sapi(牛車). Sumbu disambungkan diantara kedua roda dan diatasnya diletakkan alas. Di alas itulah orang dapat naik dan barang-barang dapat diletakkan di atasnya dan ditarik dengan menggunakan tenaga manusia, kuda atau sapi. Apabila kita perhatikan kanji kuruma di atas, dapat dijelaskan bahwa kanji kuruma (mobil) dibentuk dari gambar sumbu yang 
diletakkan pada roda gerobak. Kanji kuruma merujuk pada arti mobil atau hal-hal yang berhubungan dengan mobil.

\section{Analisis Kanji Ringan 「軽」}

Kanji karui 「軽」terdiri dari dua kanji, dimulai dengan bushu kurumahen lalu diikuti dengan kanji「圣」. Berikut adalah pembentukan dari kanji 「軽」

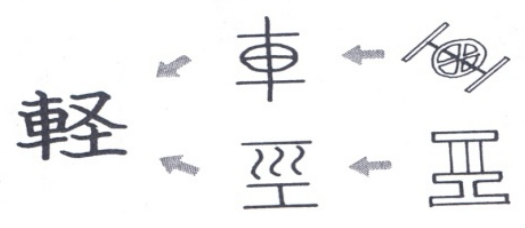

Gambar 2

Menurut Nelson (2006: 864), kanji ini memiliki arti ringan, remeh, sederhana. Kanji「軽い」 merupakan gabungan dari kanji kuruma「車」 yang memiliki arti mobil (Nelson, 2006: 864) dan kanji 「圣」. Kanji「圣」 adalah bentuk penyederhanaan dari kanji「互」 yang memiliki arti 'lurus'. (Toudou, 1990: 947). Sesuai dengan teori rikusho (Henshall, 1998 xvi), kanji「軽い」 termasuk kedalam keisei moji yaitu kanji yang menunjukkan elemen makna dengan elemen vokal. Hal ini dapat dilihat dari penggabungan kanji kuruma「車」 dengan kanji 「圣」 dimana kedua kanji tersebut menjadi bermakna 'kendaraan perang yang berjalan lurus dengan ringan'. Dari kata 'ringan'tersebut maka diambil arti dari kanji「軽い」. Penulis menganalisis bahwa memang ada keterkaitan antara kanji「車」dengan kanji「圣」 walaupun apabila dilihat dari arti kanji「圣」 tidak memiliki keterkaitan langsung dengan kanji 車」, tetapi kalau kita melihat sejarah terbentuknya kanji tersebut dimana kanji「圣」 yang memiliki arti 'lurus’ digabungkan dengan 'mobil perang yang berjalan lurus dengan ringan’ maka kanji「圣」memiliki keterkaitan dengan「車」dan ketika digabung menjadi memiliki arti 'ringan'. Sehubungan dengan hal tersebut, untuk mengetahui makna yang terhubung dalam bushu kanji「軽い」 dapat dijelaskan pada table medan makna berikut ini.

Tabel 1 Medan Makna 「軽い」

\begin{tabular}{|l|l|}
\hline \multirow{2}{*}{ 軽い } & Ringan (Matsuura, : 442) \\
\cline { 2 - 3 } & Sederhana (Nelson,2006: 866) \\
\cline { 2 - 3 } & Lembut (Weblio,2012) \\
\hline
\end{tabular}

\section{Analisis Kanji Jatuh「転ぶ」}

Kanji korobu「転ぶ」terdiri dari dua kanji, dimulai dengan bushu kurumahen lalu diikuti dengan kanji「云」. Berikut adalah pembentukan dari kanji korobu「転ぶ」. 


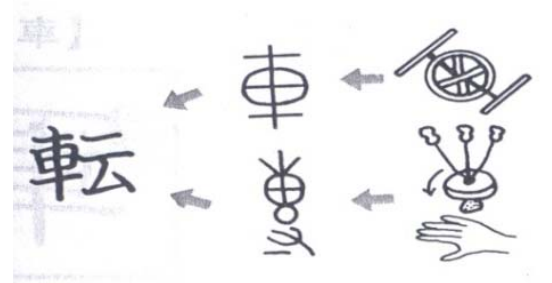

Gambar 3

Menurut Nelson (2006: 865), kanji ini memiliki arti memutar, memindahkan, mengubah. Kanji ini merupakan gabungan dari kanji kuruma「車」 yang memiliki arti 'mobil' dan kanji「云」yang memiliki arti berbicara (Nelson, 2006: 108). Kanji「云」 adalah bentuk penyederhanaan dari kanji 「専」 yang berasal dari gambar kumparan benang pancing yang digulung dengan tangan. Sesuai dengan teori rikusho (Henshall, 1998 : xvi), kanji korobu「転ぶ」 termasuk ke dalam Keisei moji yang berarti kanji yang menunjukkan elemen makna dengan elemen vokal. Hal ini dapat dilihat dari gabungan antara kanji kuruma「車」dengan kanji「専」, sehingga apabila digabung dengan kanji kuruma「車」menjadi bermakna「まるくころがる」’jatuh berguling’ (Toudou, 1982: 946). Penulis menganalisis bahwa memang ada keterkaitan antara kanji kuruma「車」 dengan kanji $「$ 云」. Apabila kita melihat asal kanji korobu「転ぶ」 yang berasal dari gambar kumparan benang pancing yang digulung dengan tangan dan kanji kuruma「車」memang terlihat tidak ada keterkaitan langsung dengan arti dari kanji korobu「転ぶ」itu sendiri, tetapi kalau melihat dari kanji kuruma「車」yang berasal dari gambar sumbu yang diletakkan pada roda gerobak, maka penulis menyimpulkan memang ada keterkaitan antara kanji「云」 dengan bushu kuruma「車」. Sehubungan dengan hal tersebut, untuk mengetahui makna yang terhubung dalam bushu kanji「転ぶ」dapat dijelaskan pada table medan makna berikut ini.

Tabel 2 Medan Makna 「転ぶ」

\begin{tabular}{|l|l|}
\hline \multirow{2}{*}{ 転ぶ } & Jatuh (Matsuura,2005: 543) \\
\cline { 2 - 2 } & Berputar (Weblio,2012) \\
\cline { 2 - 2 } & Jatuh (terguling-guling) (Nelson,2006: 865) \\
\cline { 2 - 2 } & Berputar (Weblio,2012) \\
\hline
\end{tabular}

Jadi kanji「転ぶ」merupakan kanji yang memiliki bushu kuruma dan memiliki makna ‘jatuh’.

\section{Analisis Kanji Mengirim「輸」}

Kanji $y u$ 「輸」 terdiri dari dua kanji, dimulai dengan bushu kurumahen yang memiliki arti 'mobil' (Nelson, 2006 : 864) lalu diikuti dengan bentuk「俞」. Berikut adalah pembentukan dari kanji $y u 「$ 輸」.

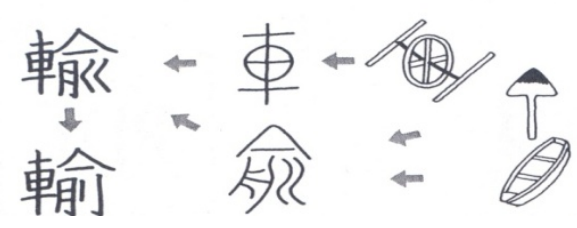

Gambar 4 
Menurut Nelson (2006: 865), kanji ini memiliki arti mengirim. Kanji ini merupakan bentuk penyederhanaan dari kanji 「輸」. Bentuk「俞」dari kanji「輸」 merupakan gabungan dari gambar perahu dan gambar alat untuk melubangi benda, dimana pada awalnya pohon diberi rongga dan dibentuk menjadi perahu. Bentuk「俞」 setelah digabung dengan bushu kuruma「車」 menjadi memiliki arti 'mengirim' (Toudou, 1982: 949). Sesuai dengan teori rikusho (Henshall, 1998: xvi), kanji $y u$ 「輸」 termasuk ke dalam kai'i moji yang merupakan kombinasi bermakna antara dua atau lebih pictographs ataupun tanda. Hal ini dapat dilihat dari gabungan dari bushu kuruma「車」dengan bentuk「俞」 dimana gabungan dari pictographs tersebut menjadi memiliki arti 'mengirim'. Penulis menganalisis bahwa pada kanji 'mengirim'「輸」juga memiliki keterkaitan dengan bushu kuruma

「車」, karena seperti yang telah dipaparkan oleh Toudou, bentuk「緰」 berasal dari pictographs pohon yang dibentuk menjadi perahu, penulis berpendapat bahwa ketika kita akan mengirim barang, selain dapat menggunakan perahu, kita juga membutuhkan sarana lain seperti mobil atau gerobak, hal ini ditunjukkan dengan bushu kuruma 「車」. Sehubungan dengan hal tersebut, untuk mengetahui makna yang terhubung dalam bushu kanji 「輸」dapat dijelaskan pada tabel medan makna berikut ini.

Tabel 3 Medan Makna「輸」

\begin{tabular}{|l|l|}
\hline \multirow{2}{*}{ 輸 } & Mengirim (Nelson,2006: 868) \\
\cline { 2 - 3 } & Transportasi (Weblio,2012) \\
\cline { 2 - 3 } & Menjadi rendah (Weblio, 2012) \\
\cline { 2 - 3 } & Mengirim (Weblio,2012 \\
\hline
\end{tabular}

Jadi kanji 「輸」 lebih tepat bila diartikan sebagai kanji yang memiliki bushu kuruma dan bermakna 'mengirim'

\section{Analisis Kanji Roda「輪」}

Kanji rin 「輪」terdiri dari dua kanji dimulai dengan bushu kurumahen「車」yang memiliki arti 'mobil' (Nelson, 2006: 864) diikuti dengan bentuk「侖」. Berikut adalah pembentukan dari kanji rin「輪」.

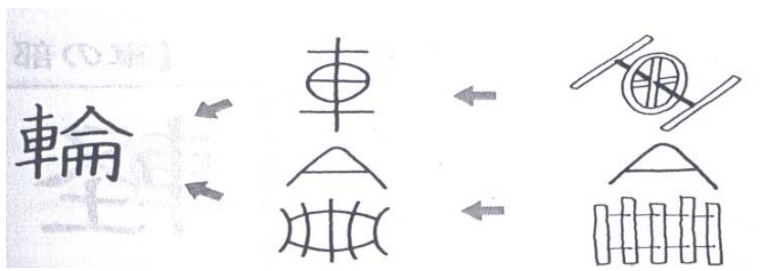

Gambar 5

Menurut Nelson (2006: 868), kanji ini memiliki arti lingkaran, roda. Bentuk「冊」dari bentuk「侖」 pada awalnya berasal dari bagian mendatar dari bambu yang diikat secara mendatar. Pada jaman dahulu bambu digunakan sebagai alat untuk menulis sebagai pengganti kertas. Tanda $\ulcorner\mathrm{A}\rfloor$ di atasnya merupakan simbol 'menggabungkan bagian yang tebal' sehingga bentuk「侖」 menjadi memililki makna 'disusun dalam urutan'dan jika digabung dengan kanji kuruma「車」 menjadi bermakna 'roda'. (Toudou,1982: 948) . Sesuai dengan teori rikusho kanji rin「輪」termasuk ke dalam keisei moji yang 
berarti kanji yang menunjukkan elemen makna dengan elemen vokal. Hal ini dapat dilihat dari gabungan antara bushu kuruma「車」dengan bentuk「侖」dan menjadi memiliki arti 'roda'. Penulis menganalisis bahwa kanji rin「輪」memiliki keterkaitan dengan bushu kuruma「車」karena hal ini dapat dilihat dari kanji kuruma「車」 yang awal pembentukan kanji itu sendiri berasal dari gambar roda dan diikuti dengan bentuk 「侖」 yang memiliki makna 'disusun dalam urutan'. walaupun keduanya tidak memiliki keterkaitan secara langsung, penulis berpendapat bahwa kanji rin「輪」 memiliki keterkaitan dengan bushu kuruma「車」. Sehubungan dengan hal tersebut, untuk mengetahui makna yang terhubung dalam bushu kanji 「輪」dapat dilihat pada tabel medan makna berikut ini.

Tabel 4 Medan Makna「輪」

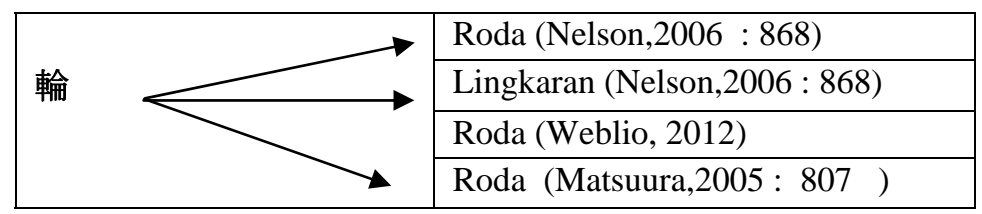

Jadi kanji 「輪」 lebih tepat bila diartikan sebagai kanji yang memiliki bushu kuruma dan bermakna 'roda' Setelah melakukan analisis pada empat kanji yang memiliki bushu kuruma, penulis mendapatkan hasil bahwa empat kanji tersebut memiliki keterkaitan langsung dengan bushu kuruma, walaupun pada kanji 「輪」tidak memiliki keterkaitan langsung dengan bushu kuruma. Selain itu dari empat kanji yang dianalisis penulis, tiga kanji yaitu kanji「軽い」、「転ぶ」dan「輪」termasuk ke dalam golongan pembentukan kanji keisei moji yaitu kanji yang menunjukkan elemen makna dengan elemen vokal sedangkan kanji「輸」 termasuk ke dalam golongan pembentukkan kanji kai’i moji yang merupakan kombinasi bermakna antara dua atau lebih pictographs ataupun tanda.

\section{PENUTUP}

Selain empat kanji yang dianalisis penulis, masih banyak lagi kanji lain yang dapat dianalisis, bukan hanya dari pembentukan kanji saja tertapi dari hal-hal lain seperti kanji-kanji yang memiliki makna yang serupa tetapi beda dalam penggunaannya. Penulis menyadari bahwa masih banyak kekurangan dalam penelitian ini dan penulis berharap mendapatkan masukan dari pembaca setelah membaca artikel ini.

\section{DAFTAR PUSTAKA}

Chaer, A. (2009). Pengantar Semantik Bahasa Indonesia. Jakarta: Rineka Cipta.

Christomy, T., dan Untung Yuwono. (2004) Semiotika Budaya. Jakarta: Pusat Penelitian Kemasyarakatan dan Budaya Direktorat Riset dan Pengabdian Masyarakat Universitas Indonesia.

Henshall, K.G. (1008). A guide to Remembering Japanese Characters Kanji. Singapura: Tuttle Publishing. 'Ippan Joushiki’. 16 Februari 2012 http://一般.常識.biz/article/110948259.html 
Keraf, G. (2007). Diksi dan Gaya Bahasa. Jakarta: Gramedia pustaka Utama, 2007

Matsuura, K. (1994). Kamus Bahasa Jepang-Indonesia. Japan : Kyoto Sangyo University Press

Nelson, A.(1994). Kamus Kanji Modern Jepang Indonesia. Indonesia : Kesaint Blanc

Parera, J. D. (2004).Teori Semantik: Edisi Kedua. Jakarta: Erlangga.

Toudou, Akiyasu. (1982). Kanji Naritachi Jiten, Japan Kyouikusha 'Weblio'. 20 Februari 2012 $<$ www.weblio.jp> 